\title{
A Review on Phytoconstituents of Ocimum (Tulsi)
}

\author{
Review article
}

\author{
Devesh Tewari ${ }^{*}$, Sah A N ${ }^{1}$, Pandey H K $^{2}$, Meena H S $^{2}$ \\ 1. Department of Pharmacognosy, Department of Pharmaceutical Sciences \\ Kumaun University Bhimtal, Uttarakhand India. \\ 2. Defense Institute of Bio-Energy Research (DIBER), DRDO, \\ Field Station, Pithoragarh-262501. (Uttarakhand) India.
}

\begin{abstract}
The use of plants as sources of medicines are human substance has been in vogue since antiquity. Large numbers of plants are utilized in various systems of medicine practiced in India and local health traditions for the treatment of human diseases since time immemorial. Among the plants known for medicinal value, the plants of genus Ocimum belonging to family Lamiaceae are very important for their therapeutic potentials. Tulsi is the legendary 'Incomparable one' of India, is one of the holiest and most cherished of the many healing and healthy giving herbs of the orient. Traditionally, Tulsi is taken in many forms: as an herbal tea, dried powder, fresh leaf, or mixed with Honey or Ghee. For centuries, the dried leaves of Tulsi have been mixed with stored grains to repel insects. Many research and studies suggest that Tulsi may be a COX-2 inhibitor, like many modern painkillers, due to its significant amount of eugenol. The chemical composition of Tulsi is highly complex, containing many nutrients and other biological active compounds. These constituents significantly vary with time, cultivation process and storage. The nutritional and pharmacological properties of the whole herb in natural form, result from synergistic interaction of many different active phytochemicals, consequently, the overall effects of Tulsi cannot be fully duplicated with isolated compound or extracts. Recent studies have shown new promising pharmacologically active chemical constituents from this ancient phytomedicine. The present review summarizes the comprehensive information concerning the traditional use, Ayurvedic properties and Phytochemistry of Tulsi.
\end{abstract}

Keywords: Ocimum, COX-2 inhibitor, eugenol, Ayurvedic properties, Phytochemistry

\section{Introduction}

The use of plants as sources of medicines are human substance has been in vogue since antiquity (1). According to a survey of World Health Organization (WHO), the practitioners of traditional system of

*Corresponding Author:

\section{Devesh Tewari}

Department of Pharmacognosy, Department of Pharmaceutical Sciences

Kumaun University Bhimtal, Nainital

Uttarakhand India.

E-mail:- dtewari3@gmail.com

Phone No: 91-9412913980 medicine treat about $80 \%$ of patients in India, $85 \%$ in Burma and $90 \%$ in Bangladesh (2, 3). India harbours about 15 percent (3000-3500) medicinal plants out of 20000 medicinal plants of the world (4). The medicinal use of plants is very old. The writings indicate that therapeutic use of plants is as old as 4000-5000 B.C. (5). Large numbers of plants are utilized in various systems of medicine practiced in India and local health traditions for the treatment of human diseases since time immemorial. Most of these medicinal plants have been identified and their uses 
are well documented by different authors (12).

The genus Ocimum comprises more than 150 species and is considered as one of the largest genera of the Lamiaceae family (13), Tulsi is described as sacred (6) and medicinal plant in ancient literature (7). The name Tulsi is derived from 'Sanskrit', which means "matchless one"( 8). Among the plants known for medicinal value, the plants of genus Ocimum are very important for their therapeutic potentials. Ocimum sanctum $L$. (Tulsi), Ocimum gratissium(Ram Tulsi), Ocimum canum (Dulal Tulsi), Ocimum basilicum (Ban Tulsi), Ocimum kilimandscharicum, Ocimum ammericanum, Ocimum camphora and Ocimum micranthum are examples ofknown important species of genus Ocimum which grow in different parts of the world and are known to have medicinal properties $(9,10,11)$.

All Ayurvedic herbs are defined by their Ayurvedic properties , these properties include:

1. Categorized according to: easily digestible or difficult to digest: Guna

2. What is it taste? sweet, sour, salty, pungent, bitter and astringent: Rasa

3. Process of digestion, metabolism and assimilation: Vipaka

4. How strong is the effect of the herb on the stomach: Virya

5. What action in the body does the food stimulate: Karma

Each Herb is described in the ancient text this way to point the way to the person so they understand the effect the herb will have on the particular body type and what is to be expected from the herb.

\section{Properties and Action:}

Rasa: Katu, Tikta, Kasaya

Guna: Laghu, Ruksa, Tikshna,

Virya: Usna

Vipaka: Katu
Karma: Dahakarta, Vranashdhaka, Hardya, Karmighna, Kaphahara, Pittahara

\section{Tulsi as an Ayurvedic medicine}

Tulsi's extracts are used in Ayurvedic remedies for common colds, headaches, stomach disorders, inflammation, heart disease, various forms of poisoning, and malaria. Traditionally, Tulsi is taken in many forms: as an herbal tea, dried powder, fresh leaf, or mixed with Honey or Ghee. Essential oil extracted from Karpoora Tulsi is mostly used for medicinal purposes and in herbal toiletry. For centuries, the dried leaves of Tulsi have been mixed with stored grains to repel insects. Many research and studies suggest that Tulsi may be a COX-2 inhibitor, like many modern painkillers, due to its significant amount of eugenol (1 - hydroxygen, 2 - methoxy - 4 allylbenzene)

Researches also give Tulsi to be effective for diabetes, by reducing blood glucose levels. The same study showed significant reduction in total cholesterol levels with Tulsi.

Another study showed that Tulsi's beneficial effect on blood glucose levels is due to its antioxidant properties. Tulsi also shows some promise for protection from radiation poisoning and cataracts.

The use of Tulsi for purification and as a medicine is widespread household medicine throughout India. Many Hindus - along with the ancient tradition of Ayurveda - believe that the healing properties of sacred herbs such as Tulsi were given by the Lord Himself, and can be used as a medicine out of reverence. Some important species of Ocimum are comprises here with some of their 
beneficial uses and phytochemical constituents.

\section{Ocimum americanum:}

General uses of importance- It represents an important source for essential oils and is used in food, perfumery and cosmetic industries. $O$. americanum L. is also grown in parts of India for flavor and fragrance industry and as a source of natural camphor, since the plant was introduced there from Kenya in the Second World War (27) Ocimum americanum L. (syn. O. canum Sims) is a resilient shrub unattacked by most plant pests and animal predators. $O$. americanum L. is used in the traditional system of medicine to treat conjunctivitis, malaria and headache. It has been reported in Somalia for its essential oils, flavones and triterpenic acids and is used for flavouring foods and in traditional medicine. In South Africa, it is often referred to as camphor basil $(22,23,24)$. In Zimbabwe, its traditional uses range from flavour and fragrance, to insect repellence and as a preservative for corpses (24-26).

Phytochemistry of species-

Terpenes, the main constituents of essential oils, play an important role in insect communication systems offering prospects of opportunities for manipulating pests (28). In the light of this, investigations on essential oils and their isolates have revealed their great potential as insect and pest control agents (28). The monoterpene 1,8-cineole, which is a constituent of the oil here analysed has been shown to be involved in cases of both direct plant defence $(29,30)$, and pollination (30). It has also been reported in allopathic effects as toxic, deterrent or inhibitory compounds (31), repellency and toxicity against three storage pests; Callosobruchusmaculatus F., Rhyzoperthadominica F., and Sitophilusoryzae L. (32). This oil contains mainly oxygenated monoterpenes which accounted for $71.24 \%$ of the oil with 18 components identified, while the nonoxygenated ones represent about $5.76 \%$ of the oil. This oil presented a very complex monoterpene fraction. The sesquiterpene and aliphatic hydrocarbons represent 8.13 and $3.58 \%$ of the total oil, respectively. Within this sesquiterpene fraction, only $1.1 \%$ was oxygenated. However, $O$. americanum oil with 10 components is qualitatively rich in aliphatic hydrocarbons but not quantitatively (33).

\section{Ocimum basilicum-}

General uses of importanceOcimum basilicum L. (sweet basil) is an annual herb which grows in several regions all over the world. The plant is widely used in food and oral care products. The essential oil of the plant is also used as perfumery (35). The leaves and flowering tops of sweet basil are used as carminative, galactogogue, stomachic and antispasmodic medicinal plant in folk medicine (36, 37). Antiviral and antimicrobial activities of this plant have also been reported $(38,39)$. There are many cultivars of basil which vary in their leaf color (green or purple), flower color (white, red,purple) and aroma (40). Basil is one of the most important medicinal and aromatic plants because of the continuous and increase demand of its products from the local and international markets. Basil essential oil is extensively used for flavoring food stuffs such as souces, vinegars, pickles, ketchups, beverages, condiments and confectionery goods. Basil essential oil is also important part of toiletry products such as mouth washes and dental creams. In perfumery basil essential oil is used for compounding certain popular perfumes and jasmine blends. Basil is also recognized as a febrifuge and antimalarial plant, infusion of the plant is used for gouty joints, cephalalgia and gargle for foul breath. Relief in irrigation for throat, earache and ring worm is also well known properties of 
basil extract (41). The leaves of basil are used in folk medicines a tonic and vermifuge, and basil tea taken hot is good for treating nausea, flatulence, and dysentery. The oil of the plant has been found to be beneficial for the alleviation of mental fatigue, colds, spasm, rhinitis, and as a first aid treatment for wasp stings and snakebites (42). O. basilicum extracts have been shown to display important effects at cellular level, including the platelet antiaggregant property and inhibitory activity against HIV-1 reverse transcriptase. In addition, infusions of $O$. basilicum are used in traditional medicine to decrease plasma lipid content in some Mediterranean areas such as the Eastern Morocco (43).

Phytochemistry of species-

In $O$. basilicum from Bangladesh, linalool and geraniol are reported as the main components (44). In the oils, obtained from aerial parts of $O$. basilicum grown in Colombia and Bulgaria, linalool and methyl cinnamate are reported as major components of volatile oils respectively $(45,46)$. Linalool and methyl eugenol are the main components of the essential oils of $O$. basilicum cultivated in Mali and Guinea (47). The observed differences may be probably due to different environmental and genetic factors, different chemotypes and the nutritional status of the plants as well as other factors that can influence the oil composition. Mixture of methyl chavicol and linalool comprise $72.5 \%$ of the oil of $O$. basilicum L. $c v$. purple. The results of this study indicate that the composition of volatile oil of purple balm cultivated in Iran is similar to those which are reported from Nigeria . On the other hands, geranial and neral were not detected in the oil of purple balm and the green basil was characterized by high content $(46.1 \%)$ of citral (geranial and neral). For determination of probable chemotypes further investigations would be required.
Glycosidically bound volatile compounds could be interesting as hidden potential of antioxidant compounds in basil or in other plants. Since volatile compounds can be released from nonvolatile glycoside precursors by enzymatic or chemical pathways during manufacturing process, these compounds can be considered as potential precursors of antioxidant substances in plant material and may contribute to the total antioxidant capacity of plants.

\section{Ocimum sanctum}

General uses of importanceOcimum sanctum Linn. popularly known as the holy basil or Tulsi in India is a home remedy for various illnesses. Traditionally, the fresh fruit and leaf juice were commonly used in the treatment of cough as demulcent, mild upper respiratory tract infection, general stress syndrome, worm infestations, superficial fungal infections, and also as a diuretic (48). This plant has been evaluated pharmacologically for immunomodulatory, antistress, antimicrobial, anti-inflammatory antiasthmatic, hypoglycemic, hypotensive and analgesic activities and found to be effective in varying degrees in the animal models. The plant has also shown significant anti-oxidant activity (50). $O$. sanctum is reported to be well tolerated upto a dose of 5-7 g/day for 3 months except for constipation in few cases (8). The crude forms of the plant and the extracts are used singularly or in combination with other herbs as a cough remedy and expectorant based on the traditional experience. An infusion of leaf had been used as anti-spasmodic in gastric disorders of children. A concoction of root of Tulsi is still being used as a diaphoretic in malarial fevers in remote areas. The seeds are mucilaginous and demulcent and are given in different ailments of genitourinary system (53). Tulsi is good for heart, stimulates digestion, reduces breathing difficulties and cough (54). It has 
also been used in the treatment of snakebite and scorpion-stings described in ancient texts by Charaka and Sushruta. Thus, every part of the plant has useful application. Even today people use different parts of this plant for treatment of various ailments based on traditional knowledge. A polyherbal formulation containing Tulsi along with other plant extracts such as Withania somnifera, Tribulus terrestris and Shilajeet treated animals showed reduction in various induced stress related outcome results and was comparable with the proven adaptogen Ginseng (52).

Phytochemistry of species-

The leaves of Ocimum sanctum contain $0.7 \%$ volatile oil comprising about $71 \%$ eugenol and $20 \%$ methyl eugenol. The oil also contains carvacrol and sesquiterpine hydrocarbon caryophyllene. Fresh leaves and stem of Ocimum sanctum extract yielded some phenolic compounds (antioxidants)such as cirsilineol, circimaritin, isothymusin, apigenin androsameric acid, and appreciable quantities of eugenol Two flavonoids, viz., orientin and vicenin from aqueous leaf extract of Ocimum sanctum have been isolated(56,57,58). Ursolic acid,apigenin, luteolin, apigenin-7-O-glucuronide, luteolin-7-Oglucuronide, orientin and molludistin have also beenisolated from the leaf extract(59). Ocimum sanctum also contains a number of sesquiterpenes and monoterpenes viz., bornyl acetate,elemene, neral, and -pinenes, camphene,campesterol, cholesterol, stigmasterol and -sitosterol(60.) The fixed oils of Ocimum sanctum revealed the presence of five fatty acids - stearic, palmitic, oleic, linoleic, linolenic acids. It is a good source of beta carotene, vitamin $\mathrm{C}$ and calcium. It also contains volatile oil (1\% including eugenol, linalool, estragol, methyl chaviol, methyl cinnamate, cileole and other terpenes), tannins, camphor, flavanoid (like luteolin, orientin, vicenin), triterpene; urolic acid, Zinc, manganese and sodium are also found using high resolution gamma ray spectrometry (61). Essential oils of Tulsi have antibacterial, antifungal and antiviral properties. $(62,63$, 64)

Pharmacological Activities:

The leaves are demulcent, diaphoretic \& expectorant in bronchitis, cough, cold \& cough \& fever. It is an insecticide antihelminthic \& deodorizer \& also has been used as laxative, stimulant $\&$ anti-inflammatory, cardiotonic \& blood purifier in hepatic disorders. It can be used for indigestion, diminished appetite $\&$ all types of malaise. The oil may applied externally for chronic ulcers, inflammation and skin disorders. $(65,66,67)$ The therapeutic calibers of essential oils extracted from the fresh leaves of Ocimum sanctum has been claimed due to the presence of eugenol which is the major constituent of essential oils a phenolic compounds (1-hydroxy -2-methoxy-4-allyl benzene). It is well reported that significant activity of eugenol, essential oil components extracted from Tulsi leaves on immune system, gastric system, Central nervous system, blood chemistry etc. In experimental animals eugenol shows antidiabetic, triglyceride cholesterol decreasing action \& other diagnostic clinical enzymes in blood serum LDH, GPT, GOT \& alkaline phosphatise describing the therapeutic potentials of Ocimum sanctum as antidiabetic, hypolipidimic, hepatoprotective agent. Eugenol also shows vasodilator effect on rabbit arterial tissues (67): Ocimum as a whole as a whole plant is used in ulcers, maggots in wounds, pneumonia, anthrax, indigestion, tympanitis (inflammation of inner ear), pain in abdomen, stoppage of urination, liver, constipation, fluke, stomach pain, cannabis poisoning, opacity of cornea, tachycardia, sore eyes, sprains. The leaves are used in bleeding, eye disease and udder infections \& wound 
healing in ruminants (68). The ethanolic extract of Tulsi leaves lead to marked lowering of blood sugar in normal glucose fed hyperglycaemic \& streptozocin induced diabetic rats. (69).

\section{Conclusion}

In conclusion it is to be found that the various Ocimum species found are very much distinguished from each other .All the species are possessing different pharmacological activities science the huge variation in the chemical composition is there. The literature will serve as a guideline for the researchers in future work related to the complex phytochemistry of the genus ocimum.

\section{References:}

1. Chauhan N.S, Medicinal and aromatic plants of Himachal Pradesh. $1^{\text {st }}$ edition; Indus publishing company New Delhi; 1999.5-6 .

2. Siddiqui H.H. Safety of herbal drugsan overview. Drugs News \& Views. 1993; 1(2);7-10 .

3. WHO survey. In medicinal plants (Eds. Haq. I.).Hamdard Foundation Press, Karachi;1993.13

4. Trivedi P.C . Ethno medical plants of India. 1ed. Avishkar publishers distributors, Jaipur (Raj.) 1993. 7 .

5. Prakash P. and Gupta N. Therapeutic uses of ocimum sanctum linn(Tulsi) with a note on eugenol and its pharmacological actions: a short review. Indian j. physiol pharmacol; 2005. 49 (2) 125-131.

6. Anonymous. Wealth of India. Vol.7. Publication and Information Directorate, CSIR, New Delhi; 1991. 79-89.

7. Kirtikar K.R, Basu B.D. Indian Medicinal Plant. $2^{\text {nd }}$ Ed. Vol. 3.Bishen Singh Mahendra Pal Singh, New Connaught Place, Dehradun; 1975. 1965-1968.

8. Ghosh G.R. Tulasi (N.O. Labiatae, Genus-Ocimum). New Approaches to
Medicine and Health (NAMAH) 1995; (3). 23-29.

9. Atal C.K, Kapoor B.M. Cultivation and utilization of medicinal plants 1989 (Eds. PID CSIR).

10. Sen P. Therapeutic potentials of Tulsi : from experience to facts. Drugs News \& Views 1993; 1(2).15-21.

11. Nagarajun S, Jain H.C, Aulakh G.S. Indigenous plants used in the control of Diabetes. In: Cultivation and utilization of medicinal plants.Editors: Atal C.K and Kapoor B.M (Published by PID CSIR) 1989. 584.

12. Jain S.K.Dictionary of Indian folk medicine and Ethno-botany.2nd edn. Deep Publication, New Delhi 1991.

13. Evans W.C. Trease and Evans Pharmacognosy .W.B. Saunders Company London; 1996. 48.

14. Bauer K, Garbe D, Surburg H. Common fragrance and flavor materials. $3^{\text {rd }}$ edition, Weinheim: Wiley-VCH; 1997. 171.

15. Sajjadi S. Analysis of the essential oils of two cultivated basil (ocimum basilicum 1.) from Iran.DARU volume 14 no.3.2006, 128-130.

16. Morales M.R, Simon J.E. New basil selections with compact inflorescences for the ornamental market, Janick $\mathbf{J}$ (ed.), Progress in new crops. Arlington: ASHS Press; 1996. 543546.

17. Phippen W.B, Simon J.E. Anthocyanins in basil (Ocimum basilicum L.) J Agr Food Chem 1998. (46) 1734-1738.

18. Grayer R.J, Kite G.C, Goldstone F.J, Bryan S.E, Paton A, Putievsky E. Infraspecific taxonomy and essential oil chemotypes in sweet basil, Ocimum basilicum. Phytochemistry 1996; (43) 1033-1039.

19. Marotti M, Piccaglia R, Giovanelli E. Differences in essential oil composition of basil (Ocimum basilicum L.) Italian cultivars related 
to morphological characteristics. J Agr Food Chem 1996; (44). 3926-3929.

20. Chalchat J.C, Garry R.P, Sidibe L, Marama M. Aromatic plants of Mali (I): Chemical composition of essential oils of Ocimum basilicum L. J Essent Oil Res 1999; (11) 375-380.

21. Miller R and Miller S. Tulsi green and Herbs. India's Holy Basil. htpp://www.omorganic.com/Tulsi23J0 3:1-6.

22. Xaasan, C.C.; Cabdulraxmaan, A.D.; Passannanti, S.; Piozzi, F.; Schmid, J.P. Plants indicated by Brazilian Indians to Central Nervous System disturbances: A bibliographical approach J.Nat. Prod. 1981, 44, 752.

23. Xaasan, C.C.; Ciilmi, C.D.; Faarax, M.X.; Passamanti, S.; Piozzi, F.; Paternostro, M. Phytochemistry 1980; (19), 2229.

24. Xaasan, C.C.; Roberts, M. Indigenous Healing Plants, Southern Book Publishers: Cape Town, South Africa 1990.

25. Gelfand M.; Mavi, S.; Drummond, R.B.; Ndemera, S.B. The Traditional Medical Practitioner in Zimbabwe, Mambo Press: Gweru, Zimbabwe 1985.

26. Watt, J.M.; Breyer-Brandwijk, M.G. The Medical and Poisonous Plants of Southern and Eastern Africa. Second ed. 1962; E. and S. Livingstone.

27. Baslas, R.K., Gupta, R. and Baals, K.K. Chemical examination of essential oils from plants of genus Anethum (Umbelliferae) oils of seeds of Anethum graveolens, Part I. Flavor, Ind 1971;. 2:241-245.

28. Kaur, S., Naik, S.N. and Maheshwari, R.C.. Composition of the essential oil of Amomum subulatum(Roxb) (Cardamom large) isolated by liquid $\mathrm{CO} 2$ extraction and steam distillation. Indian Perfumer, 1993;37(3): 249-252.

29. Raffa, K.F, Klep K.D. Defence Mechanism of Woody Plants against Fungi, Blanchette, R.A.; Biggs, A.C.
(Eds.), Springer-Verlag: Berlin; 1992; 354-390.

30. Reichardt, P.B.; Bryant, J.P.; Mattes, B.R. J. Chem. Ecol. 1990, 16, 1941.Biologically Active Natural Products; Cutler, H.;ACS Symposium Series; American Chemical Society: Washington, DC, 1988.

31. Knudson, J.T.; Tollsten, L.; Bergstorm, G. Floral scents - a checklist of volatile compounds isolated by headspace techniques Phytochemistry 1993; (33) 253-280.

32. Fischer N.H. in Ecological Chemistry and Biochemistry of Plant Terpenoids, Harborne, J.B.; Tomes-Barberan. F.A. (Eds.), Clarendon: Oxford; 1991; 377.

33. Aggarwal K.K, Tripathi A.K, Prajapati V, Kumar S. Toxicity of 1,8-cineole towards three species of stored product Coleopterans Insect Science and its Application Insect Sci. Applic. 2001; (21). 155-160.

34. Matasyohj C, Bendera M. M, Ogendo. Volatile leaf oil constituents of Ocimum americanum 1. occuring in Western Kenya. J.O. Bull. chem. soc. ethiop.2006, 20(1), 177-180.

35. Bauer K, Garbe D, Surburg H. Common fragrance and flavor materials. $3^{\text {rd }}$ edition, Weinheim: Wiley-VCH; 1997. 171.

36. Chiej R. The Macdonald encyclopedia of medicinal plants. London: Macdonald and Co (Publishers) Ltd.; 1988. 207.

37. Duke J.A. CRC handbook of medicinal herbs. Boca Raton: CRC Press; 1989. p. 333.

38. Chiang L.C, Cheng P.W, Chiang W, Lin C.C. Antiviral activity of extracts and selected pure constituents of Ocimum basilicum. Cli. Exp. Pharmacol Physiol 2005; (32) 811816.

39. Baratta M.T, Dorman HJD, Deans S.G, Figueiredo A.C, Barroso J.G, Ruberto G. Antimicrobial and antioxidant properties of some commercial 
essential oil. Flav.Fragr J 1998; (13) 235-234.

40. Morales M.R, Simon J.E. New basil selections with compact inflorescences for the ornamental market, In: Janick J (ed.), Progress in new crops. Arlington: ASHS Press; 1996. 543546.

41. Hussain A.I, Anwar F, Sherazi STH, Przybylski R. Chemical composition, an antioxidant and antimicrobial activity of basil (Ocimum basilicum) essential oils depends on seasonal variations.Food Chem., 2008;(108) 986-995.

42. Baytop T: Treatment with Plants in Turkey, Istanbul, Turkey, Istanbul Univ. 1984 Publ., No. 3255.

43. Okazaki K, Nakayama S, Kawazoe K. Takaishi, Y, Antiaggregant Effects on Human Platelets of Culinary Herbs. Phytother.Res. 1998; (12) 603.

44. Mondello L, Zappia G, Cotroneo A, Bonaccorsi I, Chowdhury J.U, Usuf M, Dugo G. Studies on the chemical oilbearing plants of Bangladesh. Part VIII. Composition of some Ocimum oils, $O$. basilicum L. var. purpurascens; $O$. sanctum L. green; $O$. sanctum $\mathrm{L}$. purple; $O$. americanum L., citral type; $O$. americanum L., camphor type.FlavFragr J 2002; (17) 335-340.

45. Vina A, Murillo E. Essential oil composition from twelve varieties of basil (Ocimum spp) rown in Colombia. J Brazil ChemSoci 2003; (14) 744-749.

46. Jirovetz L, Buchbauer G. Analysis, chemotype and quality control of the essential oil of new cultivated basil (Ocimum basilicum L.) plant from Bulgaria. Scientia Pharmaceutica 2001; (69) 85-89.

47. Keita S.M, Vincent C, Schmit J.P, Belanger A. Essential oil composition of Ocimum basilicum L., O. gratissium L. and $O$. suave L. in the Republic of Guinea. Flav.Fragr J 2000; 339-341.
48. Nadkarni A.K. Indian material medica Vol-I, Popular Prakashan Bombay; 1993. 865-866.

49. Williamson E.M. Ocimum sanctum.Major herbs of Ayurveda. London, Churchill Livingstone publication; 2002. 201-205.

50. Yanpallewar S.U, Rai S, Kumar M, Acharya S.B. Evaluation of antioxidant and neuroprotective effectof Ocimum sanctum on transient cerebral ischemia and long term cerebral hypoperfusion. Pharmacol.Biochem.Behav 79(1), 2004; 155-164.

51. Dhar M.L, Dhar M.M, Dhawan B.N, Mehrotra B.N, Ray C. Screening of Indian plants for biological activity: Part I. Indian Journal of Experimental Biology 1968; (6) 242-248.

52. Bhattacharya S.K, Bhattacharya A, Chakrabarti A. Adaptogenic activity of Siotone, a polyherbal formulation of Ayurvedic rasayanas. Indian J.Exp.Biol.2000; ( 38) 119-128.

53. Gupta S, Mediratta P.K, Singh S, Sharma K.K, Shukla R. Antidiabetic, antihypocholestrolaemic and antioxidant effect of Ocimum sanctum (Linn) seed oil. Indian $J$ Exp.Biol.2006; (44) 300- 304.

54. Chandra A, Mahdi A.A, Singh R.K, Mahdi F, Chander R. Effect of Indian herbal hypoglycemic agents on antioxidant capacity and trace elements content in diabetic rats. J.Med Food .2008; (11). 506-512.

55. Reddy S.S, Karuna R, Baskar R, Saralakumari D. Prevention of insulin resistance by ingesting aqueous extract of Ocimum sanctum to fructose fed rats. Horm.Metaboism Res 2008; (40) 44-49.

56. Gupta S.K, Prakash J, Srivastava S. Validation of traditional claim of Tulsi, Ocimum sanctum Linn. as a medicinal plant. Indian J. Exp. Biol. 2002; (40). 765-773.

57. Shah C.S, Qadry J.S. A Text Book of Pharmacognosy. 11th ed. New Delhi: 
B S Shah Prakashan; 1995 reprint 1998. 216.

58. Yanpallewar S.U, Rai S, Kumar M, Acharya S.B. Evaluation of antioxidant and neuroprotective effectof Ocimum sanctum on transient cerebral ischemia and long term cerebral hypoperfusion. Pharmacol. Biochem. Behav 79(1) 2004;155-164.

59. Nair AGR, Gunasegaran R, Joshi B.S. Chemical investigation of certain south Indian plants. Indian J.Chem (21)1982; 979.

60. IDMA. Indian Herbal Pharmacopoeia. Mumbai, India: 2002. 272 p.

61. Singh S, Majumdar D.K, Rehan HMS.Evaluation of anti-inflammatory potential of fixed oil of Ocimum sanctum (Holy basil) and its possible mechanism of action..J.of Ethnopharmacoogy; 1996; (54) . 1926.

62. Singh S, Malhotra M, Majumdar D. K.Antibacterial activity of Ocimum sanctum L. fixed oil. Indian $J$ Exp Biology; 2005; 43(9). 835-837.

63. Geetha R K, Vasudevan D M, Kedlaya R, Deepa S, Ballal M. "Activity of Ocimum sanctum against the enteric pathogens." Indian Journal of Medical Sciences, 2001; 55(8). 434-438.
64. Parida M; Pandya G; Bhargava R; Jana A.M. "Assessment of in vitro antiviral activity of certain indigenous plants against polio virus type-3." Indian Journal of Virology; 1997; 13(2). 101105.

65. Singh S, Aggarwal S.S. Antiasthmatic \& anti-inflammatory activity of ocimum sanctum. International Journal of pharmacognosy. 1991; 29(4). 306.

66. Ganasoundri A. Devi P.U, Rao B.S.Enhancement of bone marrow radio protection $\&$ reduction of W.R2721 toxicity of Ocimum sanctum. Mutation research 1998; 397(2).303

67. Aruna K, Sivarama Krishnan V.M. Anticarcinogenic effects of the essential oils from cumin, poppy \& basil. Phytotherapy research.1996; (10).577.

68. Singh S. Majmudar D.K, Yadav M.R. Chemical \& pharmacological study on fixed oil of ocimum sanctum. Indian journal of experimental biology 1996;34 (12).1212p.

69. Skaltsa M, Couladi M , Philianos S, Singh M. Phytochemical studies of the leaves of Ocimum sanctum : fitotdepia 1987;58(4) 286. 